medRxiv preprint doi: https://doi.org/10.1101/2020.05.21.20051300; this version posted August 18, 2020. The copyright holder for this preprint (which was not certified by peer review) is the author/funder, who has granted medRxiv a license to display the preprint in perpetuity.

Balnis et.al.

\title{
Unique inflammatory profile is associated with higher SARS-CoV-2 acute respiratory distress syndrome (ARDS) mortality.
}

Joseph Balnis ${ }^{1,2}$, Alejandro P. Adam ${ }^{1,3}$, Amit Chopra ${ }^{1}$, Hau C. Chieng ${ }^{1}$, Lisa A. Drake², Nina Martino², Ramon B. Ramos ${ }^{2}$, Paul J. Feustel ${ }^{4}$, Katherine A. Overmyer ${ }^{5}$, Evgenia Shishkova ${ }^{6}$, Joshua J. Coon ${ }^{5,6}$, Harold A. Singer ${ }^{2}$, Marc A. Judson ${ }^{1}$, Ariel Jaitovich ${ }^{1,2^{*}}$

1Division of Pulmonary and Critical Care Medicine, ${ }^{2}$ Department of Molecular and Cellular Physiology, ${ }^{3}$ Ophthalmology and ${ }^{4}$ Neuroscience and Experimental Therapeutics, Albany Medical College, Albany, NY. ${ }^{5}$ Morgridge Institute for Research, Madison, WI; ${ }^{6}$ Department of Biomolecular Chemistry, University of Wisconsin-Madison, Madison, WI

Running title: Circulating inflammatory profile and COVID19 mortality

"Address for reprint requests and other correspondence: A. Jaitovich, Albany Medical College, 47 New Scotland Ave., Albany, NY 12208 (e-mail: jaitova@amc.edu).

Keywords: Cytokines, chemokines, COVID19, mortality, IL1RA

Total words count: 3872 
medRxiv preprint doi: https://doi.org/10.1101/2020.05.21.20051300; this version posted August 18, 2020. The copyright holder for this preprint (which was not certified by peer review) is the author/funder, who has granted medRxiv a license to display the preprint in perpetuity.

It is made available under a CC-BY-NC 4.0 International license .

Balnis et.al.

Abstract: The COVID19 pandemic is likely to cause more than a million of deaths worldwide, primarily due to complications from COVID19-associated acute respiratory distress syndrome (ARDS). Controversy surrounds the circulating cytokine/chemokine profile of COVID19-associated ARDS, with some groups suggesting that it is similar to non-COVID19 ARDS patients and others observing substantial differences. Moreover, while a hyperinflammatory phenotype associates with higher mortality in non-COVID19 ARDS, there is little information on the inflammatory landscape's association with mortality in COVID19 ARDS patients. Even though the circulating leukocytes' transcriptomic signature has been associated with distinct phenotypes and outcomes in critical illness including ARDS, it is unclear whether the mortality-associated inflammatory mediators from COVID19 patients are transcriptionally regulated in the leukocyte compartment. Here, we conducted a prospective cohort study of 41 mechanically ventilated patients with COVID19 infection using highly calibrated methods to define the levels of plasma cytokines/chemokines and their gene expressions in circulating leukocytes. Plasma IL1RA and IL8 were found positively associated with mortality while RANTES and EGF negatively associated with that outcome. However, the leukocyte gene expression of these proteins had no statistically significant correlation with mortality. These data suggest a unique inflammatory signature associated with severe COVID19. 
medRxiv preprint doi: https://doi.org/10.1101/2020.05.21.20051300; this version posted August 18, 2020. The copyright holder for this preprint (which was not certified by peer review) is the author/funder, who has granted medRxiv a license to display the preprint in perpetuity.

It is made available under a CC-BY-NC 4.0 International license .

Balnis et.al.

Introduction: The COVID19 pandemic has so far caused over seven hundred thousand deaths worldwide, primarily due to complications from acute respiratory distress syndrome (ARDS) ${ }^{1}$. Controversy surrounds the circulating cytokine/chemokine profile of COVID19-associated ARDS, with some groups suggesting that it is similar to non-COVID19 ARDS patients ${ }^{2}$ and others observing substantial differences ${ }^{3}$. Non-COVID ARDS patients who develop a hyperinflammatory signature have a higher mortality than those demonstrating a hypo-inflammatory phenotype; furthermore, these subgroups have different responses to specific interventions such as positive end expiratory pressure (PEEP), administration of simvastatin, and fluid management ${ }^{4-8}$. However, the clinical effects of the inflammatory profile on severe COVID19 infection remains controversial ${ }^{9}$. Moreover, descriptions of the inflammatory signatures in COVID19 patients have been reported using standard clinical laboratory tests $^{10-16}$ or multiplex systems ${ }^{3,16,17}$ that lack adequate methodological calibration of individual cytokines $^{9,18}$. A more precise characterization of circulating cytokine/chemokine expression profile in COVID19-associated ARDS could lead to the development of personalized therapies directed against specific inflammatory signatures ${ }^{19,20}$. Also, because distinct transcriptional signatures in circulating leukocytes have been associated with mortality in critical illness including ARDS ${ }^{21,22}$, it is rational to postulate that COVID19 mortality-associated cytokines are transcriptionally regulated in leukocytes or other sources. Thus, cytokine gene expression levels in circulating leukocytes could provide important insights into the organ-specific regulation of the inflammatory response in COVID19 patients.

In this study, we prospectively interrogated the plasma cytokine/chemokine levels and their leukocyte gene expression in patients with severe COVID19 infection using validated methods. We hypothesized that specific signatures would be associated with mortality in this setting. Portions of this study have been recently reported in a preprint form ${ }^{23}$. 
medRxiv preprint doi: https://doi.org/10.1101/2020.05.21.20051300; this version posted August 18, 2020. The copyright holder for this preprint (which was not certified by peer review) is the author/funder, who has granted medRxiv a license to display the preprint in perpetuity. It is made available under a CC-BY-NC 4.0 International license .

Balnis et.al.

Methods: We conducted a prospective cohort study involving 41 patients with diagnosis of COVID19 who were admitted to the Albany Medical Center Intensive Care Unit (ICU) and required mechanical ventilation due to ARDS. These patients were enrolled between March 20 and April 17, 2020. Ethical approval was obtained from Albany Medical College Committee on Research Involving Human Subjects (IRB\# 5670-20). Patients were considered for enrollment if they were older than 18 years and were admitted to the ICU for invasive mechanical ventilation due to COVID19-associated respiratory failure. Exclusion criteria included likely imminent death or inability to provide consent. Consent was obtained from the patient or a legally authorized representative. Acute illness severity was assessed using the Sequential Organ Failure Assessment (SOFA) score, Simplified Acute Physiology Score (SAPS II) and the Acute Physiology and Chronic Health Evaluation (APACHE II) score ${ }^{24}$. Chronic disease burden information was aggregated with the Charlson Comorbidity index ${ }^{25}$. COVID19 diagnosis was confirmed with regular polymerase chain reaction (PCR) method. Ventilatory system static compliance was obtained at the time of enrollment with patients supported with volume-control ventilatory mode and under full sedation.

Cytokines measurements: At the time of enrollment, blood samples were obtained and immediately centrifuged for plasma fractionation. Samples were frozen for later cytokine/chemokine determinations using a Human XL Cytokine Magnetic Luminex-Discovery Fixed Panel (R\&D Systems \#LKTM014) performed simultaneously in duplicates within a week of enrollment completion. Only one freeze-thaw cycle occurred. Cytokines that were found associated with mortality with the multiplex system were later individually measured with enzyme-linked immunosorbent assay (ELISA) using a plate reader (Cytation 5 Imager, BioTek, Winooski, VT), see assays catalogue numbers in supplemental Table S1.

Leukocyte messenger RNA (mRNA) expression determination: In addition to plasma samples, whole blood samples were simultaneously collected from all participants, and leukocytes were isolated 
medRxiv preprint doi: https://doi.org/10.1101/2020.05.21.20051300; this version posted August 18, 2020. The copyright holder for this preprint (which was not certified by peer review) is the author/funder, who has granted medRxiv a license to display the preprint in perpetuity.

It is made available under a CC-BY-NC 4.0 International license .

Balnis et.al.

using LeukoLOCK ${ }^{\circledR}$ filtering system (catalog no. AM1923; Thermo Fisher). RNA was then extracted from peripheral leukocytes with TRIzol reagent (catalog no. 15596018; Thermo Fisher), and total RNA was isolated following manufacturer's instructions. Four hundred nanograms of total RNA were used to prepare cDNA using Primescript RT Master Mix at $42^{\circ} \mathrm{C}$ (catalog no. RR036A; Takara) following manufacturer's instructions. The cDNA was diluted 10 -fold in nuclease-free water, and then, $2 \mu \mathrm{L}$ of cDNA were used per PCR reaction. qPCR was performed in a StepOnePlus (Applied Biosystems) instrument using SYBR green- based iTaq supermix (catalog no. 1725125; Bio-Rad) and 2 pmol primers (Eurofins or Thermo Fisher). Fold induction was calculated using the $\Delta \Delta$ Ct method using GAPDH as the reference gene. Each sample was assayed in duplicate and a negative control was included in each experiment. Primer sequences are listed in supplemental Table S2.

Statistical analysis: Due to the long hospital course of severe COVID19 infection ${ }^{26}$, especially in patients receiving mechanical ventilation, the analyzed outcome variable was mortality at day 45 post enrollment. Median (interquartile ranges [IQRs]) and frequency (\%) were used to report ICU patient baseline characteristics for continuous and categorical variables, respectively. Associations between mortality and cytokine/chemokine levels obtained with the multiplex Luminex system were analyzed with ANOVA, with $p$ value $<0.05$ considered significant. As multiplex systems require a second inferential step to adjust for false discovery rate (FDR), and because that step can lead to false negative and positive results ${ }^{18}$, any cytokine/chemokine that were found statistically significantly associated with mortality before adjustment for FDR were individually measured with ELISA. For that test, comparison between cytokines/chemokines soluble levels in surviving versus non-surviving patients was accomplished with Student t-test, and a $p$ value of $<0.05$ was considered significant. Association of leukocyte gene products magnitudes in leukocytes with patients' mortality was done using with Student t-test, and a $p$ value $<0.05$ was considered significant. 
medRxiv preprint doi: https://doi.org/10.1101/2020.05.21.20051300; this version posted August 18, 2020. The copyright holder for this preprint (which was not certified by peer review) is the author/funder, who has granted medRxiv a license to display the preprint in perpetuity.

It is made available under a CC-BY-NC 4.0 International license .

Balnis et.al.

Results: A total of 41 patient were enrolled. The average age of the cohort was 60 years old and there was a significant male sex predominance (68\%). 27\% were Caucasians, $12 \%$ African Americans, $31 \%$ Hispanics and $30 \%$ other ethnicities. Consistent with previous reports, we found that African Americans and Hispanics had significantly higher mortality than Caucasians ${ }^{27}$. Average APACHE II, SAPS II and SOFA scores were 24, 60 and 9.5 respectively. Other important baseline characteristics are presented in Table 1.

Association of cytokine/chemokine circulating levels with mortality: A total of 45 cytokines/chemokines were measured, and 7 were found associated with mortality with the multiplex system, with RANTES, EGF, IL1a and IL5 associated with lower mortality, and IL1RA, IL8 and CCL19 associated with greater mortality (Figure 1-A). The complete dataset including all the cytokines/chemokines, covariables, and outcomes can be found in the https://figshare.com/articles/dataset/Supplemental file/12808316. IL6, which is associated with worse outcomes in non-COVID19 ARDS, was found unassociated with mortality in this cohort. Out of the 7 cytokines/chemokines that were associated with mortality, individual ELISA determinations confirmed the positive associations of IL1RA and IL8 and negative associations of RANTES and EGF with mortality (Figure 2). IL5 and CCL19 levels were unassociated with mortality and IL1a was not detected by the assay (see supplemental Figure S1).

\section{Association of cytokine/chemokine gene expression levels in circulating leukocytes with their} respective protein product and with mortality: Cytokine/chemokine gene expression levels in circulating leukocytes were not significantly associated with mortality. EGF and RANTES gene expression were modestly but significantly correlated with their respective protein products' circulating levels, whereas mRNA expression and circulating levels of the other factors were not (Table 2). 
medRxiv preprint doi: https://doi.org/10.1101/2020.05.21.20051300; this version posted August 18, 2020. The copyright holder for this preprint (which was not certified by peer review) is the author/funder, who has granted medRxiv a license to display the preprint in perpetuity.

It is made available under a CC-BY-NC 4.0 International license .

Balnis et.al.

Discussion: We describe a cytokine/chemokine landscape associated with COVID19 mortality, which is different from the one observed in non-COVID19-associated ARDS: Higher IL1RA and IL8, and reduced levels of RANTES and EGF were associated with mortality at 45 days.

The soluble cytokines and chemokines profile associated with COVID19 ARDS and its relationship to mortality has been recently debated and remains incompletely understood ${ }^{9}$. Multiple large ARDS trials have found robust elevations of interleukin (IL)-6 $6^{5-7}$, and both IL6 and IL8 associate with worse outcomes in that setting ${ }^{28}$. We identified IL8, but not IL6, to be associated with higher mortality in our cohort, suggesting an overlapping but distinct inflammatory signature of COVID19-driven respiratory failure. Consistent with a very recent report ${ }^{17}$, we found IL1 receptor antagonist (IL1RA) to be associated with higher mortality in COVID19. Significantly, while we found that IL1RA levels positively associate with mortality, multiple previous reports indicate that it confers protection against ARDS in non-COVID19 patients. IL1RA is a natural inhibitor of the pro-inflammatory IL1 $\beta$, which is a highly active cytokine found in the lungs of patients with non-COVID19 ARDS ${ }^{28-30}$. IL1 $\beta$ has been found to increase alveolar permeability both in animals and in humans ${ }^{31,32}$, and experimental models of IL1 $\beta$-induced lung injury are mitigated by IL1RA administration ${ }^{33}$. Reduced levels of IL1RA in bronchioalveolar lavage samples are associated with higher mortality of $\mathrm{ARDS}^{34}$ and IL1RA administration has been proposed as a measure to attenuate lung injury ${ }^{35,36}$. Moreover, a single nucleotide polymorphism (SNP) leading to higher plasma IL1RA levels is associated with reduced ARDS susceptibility ${ }^{37}$. These data suggest that IL1RA elevation represents a feature of COVID19-induced respiratory failure that differs from nonCOVID19 ARDS, and the potential pharmacologic modulation of IL1 ra has been recently suggested for COVID19 patients 38,39 .

Our finding that RANTES (CCL5) is negatively associated with mortality in our cohort is consistent with a recent report indicating that it may protect COVID19 patients from developing severe disease ${ }^{3}$. 
medRxiv preprint doi: https://doi.org/10.1101/2020.05.21.20051300; this version posted August 18, 2020. The copyright holder for this preprint (which was not certified by peer review) is the author/funder, who has granted medRxiv a license to display the preprint in perpetuity.

It is made available under a CC-BY-NC 4.0 International license .

Balnis et.al.

RANTES is produced by CD8+ T cells after antigen stimulation and competes with the HIV virus for the CCR5 receptor binding ${ }^{40}$; RANTES could operate in a similar fashion in COVID19 infections. Indeed, a recent study demonstrates that a clonal expansion of CD8+ T cells in broncho-alveolar fluid is associated with milder forms of COVID-19 infection ${ }^{41}$.

There is a growing interest in the value of leukocyte gene expression profiles to define ARDS and sepsis phenotypes and in establishing their association with mortality ${ }^{22,42}$. Indeed, recent data indicates that corticosteroids could be beneficial in certain patient subgroups demonstrating specific leukocyte transcriptomic signatures ${ }^{19,43}$. To gain insight into the regulation of mortality-associated inflammatory mediators in COVID19, we determined the expression levels of the different mortality-associated cytokine and chemokine genes in circulating leukocytes, and found that while some of the interrogated gene expression levels were modestly correlated with the magnitude of circulating soluble protein, none of them were associated with mortality. While future research could elucidate the source of the mortality-associated inflammatory mediators in COVID19, we speculate that the cytokine profile in these patients could be contributed by cells other than circulating leukocytes such as the bronchusassociated lymphoid tissue (BALT) ${ }^{44}$ or by subpopulations of circulating immune cells such as NK cells and others ${ }^{45}$, whose gene expression levels may not be captured with the global leukocyte mRNA analysis. It is also possible that the turnover of these proteins is regulated at the post transcriptional level and thus their expression may not be reflected by the magnitude of mRNA expression.

A main strength of this work is that we describe a prospective cohort of COVID19 ARDS patients and analyzed the association between circulating cytokines and chemokines with mortality. In addition, we determined plasma cytokine levels with ELISA, as opposed to relying on less calibrated clinical laboratory or multiplex testing systems. Indeed, the lack of individual ELISA assays in the current COVID19 literature is considered an important factor that complicates comparing these studies with the non-COVID-associated ARDS trials ${ }^{9}$. Our study has some limitations. First, this is a single-center study 
medRxiv preprint doi: https://doi.org/10.1101/2020.05.21.20051300; this version posted August 18, 2020. The copyright holder for this preprint (which was not certified by peer review) is the author/funder, who has granted medRxiv a license to display the preprint in perpetuity.

It is made available under a CC-BY-NC 4.0 International license.

Balnis et.al.

that may not be universally reflective of COVID19 ARDS patients. Second, we did not have access to an external validation cohort. However, the associations between IL1RA and worse outcomes and RANTES with better outcomes in COVID-ARDS have been replicated by two recently published studies ${ }^{3,17}$. Third, while we enrolled the patients at the time of hospital admission, we had no control over the period elapsed between the disease development and the blood sampling, which may have affected the inflammatory landscape. Fourth, we had no control of different drugs administered to the patients which could have impacted their inflammatory profile.

Conclusion: Higher IL1RA and IL8 levels in plasma are positively associated with mortality in a cohort of critically ill COVID19 patients. Elevated RANTES and EGF protein are negatively associated with mortality in these patients. We found no association between gene expression of these cytokines in circulating leukocytes with mortality. While our data indicate that a unique inflammatory signature is associated with severe COVID19 mortality, future research could determine the value of these mediators' measurements as mortality-predictive biomarkers; and define if their pharmacologic modulation could improve severe COVID19 prognosis. 
medRxiv preprint doi: https://doi.org/10.1101/2020.05.21.20051300; this version posted August 18, 2020. The copyright holder for this preprint (which was not certified by peer review) is the author/funder, who has granted medRxiv a license to display the preprint in perpetuity. It is made available under a CC-BY-NC 4.0 International license.

Balnis et.al.

Disclosures: None

Research Support: Part of the results reported herein have been funded by NHLBI of the National Institutes of Health under the award number K01-HL130704 (AJ), and by the Collins Family Foundation Endowment (AJ); NIH/NHLBI 5R01HL049426 (HAS); NIH/National Institute of General Medical Sciences Grant 1R01GM124133 (APA); P41 GM108538 (KAO, ES, JJC).

Authors Contributions: JB, APA, KAO, ES, JJC, PJF, HAS, MAJ and AJ: Conception and research design, data interpretation and manuscript editing. AC, AJ and HCC: Patients' enrollments and clinical data collection. APA and NM: multiplex cytokines measurements. JB and LAD: ELISA determinations. RBR: RT-qPCR experiments. 
medRxiv preprint doi: https://doi.org/10.1101/2020.05.21.20051300; this version posted August 18, 2020. The copyright holder for this preprint (which was not certified by peer review) is the author/funder, who has granted medRxiv a license to display the preprint in perpetuity.

It is made available under a CC-BY-NC 4.0 International license .

Balnis et.al.

$\underline{\text { Table and figures legends }}$

\begin{tabular}{|c|c|c|c|c|}
\hline Variables & Entire cohort & Survived & Died & P-value \\
\hline Sex- N (\%) & $n=41$ & $n=26$ & $n=15$ & \\
\hline Male & $28(68.3 \%)$ & $19(73.1 \%)$ & $9(60.0 \%)$ & 0.38 \\
\hline Female & $13(31.7 \%)$ & $7(26.9 \%)$ & $6(40.0 \%)$ & 0.38 \\
\hline \multicolumn{5}{|l|}{ Age (IQR) } \\
\hline & $62(50-72)$ & $56(50-66)$ & $68(62-73)$ & 0.11 \\
\hline \multicolumn{5}{|l|}{ Ethnicity- N (\%) } \\
\hline White & $11(26.8 \%)$ & $6(23.1 \%)$ & $5(33.3 \%)$ & 0.48 \\
\hline African American & $5(12.2 \%)$ & $1(3.8 \%)$ & $4(26.7 \%)$ & $0.03^{*}$ \\
\hline Asian & $2(5.9 \%)$ & $1(3.8 \%)$ & $1(6.7 \%)$ & 0.69 \\
\hline Hispanic & $13(31.7 \%)$ & $9(34.9 \%)$ & $4(26.7 \%)$ & 0.53 \\
\hline Other & $10(24.4 \%)$ & $9(34.9 \%)$ & $1(6.7 \%)$ & $0.04^{\star}$ \\
\hline \multicolumn{5}{|l|}{ Comorbidities- $\mathbf{N}(\%)$} \\
\hline Congestive heart failure & $1(2.4 \%)$ & $1(3.8 \%)$ & $0(0 \%)$ & 0.44 \\
\hline Pulmonary disease & $6(14.6 \%)$ & $4(15.4 \%)$ & $2(13.3 \%)$ & 0.85 \\
\hline Diabetes mellitus & $16(39.1 \%)$ & $10(38.5 \%)$ & $6(40.0 \%)$ & 0.92 \\
\hline Renal disease & $4(9.8 \%)$ & $1(3.8 \%)$ & $3(20.0 \%)$ & 0.09 \\
\hline Cancer & $2(4.9 \%)$ & $1(3.8 \%)$ & $1(6.7 \%)$ & 0.69 \\
\hline HIVIAIDS & $1(2.4 \%)$ & $1(3.8 \%)$ & $0(0 \%)$ & 0.44 \\
\hline Charlson score index & $2(1.0-4.0)$ & $1(1.0-3.0)$ & $3(2.0-5.5)$ & 0.12 \\
\hline \multicolumn{5}{|l|}{ Severity scores (IQR) } \\
\hline APACHEII & $23(18.5-28.5)$ & $21.5(18.3-24.8)$ & $28(23.0-33.5)$ & $0.02^{*}$ \\
\hline SAPS ॥ & $58(50.5-68.5)$ & $57(51-59)$ & $65(54-74)$ & 0.11 \\
\hline SOFA & $8(7.00-12.0)$ & $8(7.00-10.8)$ & $11(7.50-12.5)$ & 0.14 \\
\hline \multicolumn{5}{|l|}{ Biomarkers (IQR) } \\
\hline Ferritin (NG/mL) & $768(377-1259)$ & $717(375-1272)$ & $991(681-1111)$ & 0.37 \\
\hline CRP (MG/L) & $192(73.1-257)$ & $195(75.3-258)$ & $166(79.5-243)$ & 0.35 \\
\hline D-dimer (MG/L FEU) & $11.5(2.12-25.7)$ & $6.28(1.87-20.8)$ & $18.8(4.89-37.1)$ & 0.22 \\
\hline Procalcitonin (NG/mL) & $1.40(0.47-4.34)$ & $1.45(0.28-2.78)$ & $1.75(0.91-11.5)$ & 0.49 \\
\hline Lactate $(\mathrm{mmol} / \mathrm{L})$ & $1.20(0.91-1.51)$ & $1.32(0.89-1.52)$ & $1.13(0.95-1.29)$ & 0.20 \\
\hline Fibrinogen (MG/DL) & $520(412-686)$ & $520(412-686)$ & $520(443-658)$ & 0.97 \\
\hline \multicolumn{5}{|l|}{ Respiratory variables (IQR) } \\
\hline $\mathrm{P} / \mathrm{F}$ ratio $(\mathrm{mmHg})$ & $145(98.0-203)$ & $159(128-214)$ & $128(84.5-155)$ & $0.03^{*}$ \\
\hline Static compliance $(\mathrm{mmHg})$ & $38.5(28.38-45.1)$ & $39.2(29.3-44.9)$ & $37.6(28.5-44.8)$ & 0.38 \\
\hline \multicolumn{5}{|l|}{ Treatment- N (\%) } \\
\hline ECMO & $2(4.9 \%)$ & $1(3.8 \%)$ & $1(6.7 \%)$ & 0.69 \\
\hline Antibiotics & $41(100 \%)$ & $26(100 \%)$ & $15(100 \%)$ & NA \\
\hline Hydroxychloroquine & $38(92.7 \%)$ & $24(92.3 \%)$ & $14(93.3 \%)$ & 0.90 \\
\hline Antiviral & $1(2.4 \%)$ & $1(3.8 \%)$ & $0(0 \%)$ & 0.44 \\
\hline IL6- Antagonist & $2(4.9 \%)$ & $1(3.8 \%)$ & $1(6.7 \%)$ & 0.69 \\
\hline Convalescent Plasma & $16(39.1 \%)$ & $8(30.8 \%)$ & $8(53.3 \%)$ & 0.15 \\
\hline Steroids & $28(68.3 \%)$ & $19(73.1 \%)$ & $9(60.0 \%)$ & 0.38 \\
\hline
\end{tabular}

Table 1: Patients' baseline characteristics in the whole cohort. Comparison of clinical and laboratory variables between surviving versus non surviving patients. Data are presented as median with interquartile range (IQR); unless otherwise indicated. APACHE II: Acute Physiology and Chronic Health Evaluation II; SAPS II: Simplified Acute Physiology Score; SOFA: Sequential Organ Failure Assessment. ECMO: Extracorporeal membrane oxygenation; CRP: C-reactive protein. Significant $p$ values are indicated in bold and italic font. $P$ values for categorical variables are from chi-square tests of association or Fisher's exact tests when the expected value in any cell is five or less. P values for continuous variables are from Student's t-test or for non-normal distributed variables by Mann-Whitney rank test. 
medRxiv preprint doi: https://doi.org/10.1101/2020.05.21.20051300; this version posted August 18, 2020. The copyright holder for this preprint (which was not certified by peer review) is the author/funder, who has granted medRxiv a license to display the preprint in perpetuity.

It is made available under a CC-BY-NC 4.0 International license .

Balnis et.al.

\begin{tabular}{|lll|c|}
\hline \multicolumn{2}{|c|}{ Table 2: Correlations with leukocyte mRNA } & \\
Cytokine & with soluble protein & with mortality \\
RANTES & R-squared & P-value & P-value \\
EGF & 0.2318 & $<0.01^{\star *}$ & 0.28 \\
L-1ra & 0.3277 & $<0.001^{\text {*** }}$ & 0.25 \\
L-8 & 0.0729 & 0.10 & 0.86 \\
\hline
\end{tabular}

Table 2: Correlation between cytokine/chemokine gene expression in circulating leukocytes with soluble protein and with mortality. Significant $p$ values are indicated in bold and italic font.

\section{Figure 1}

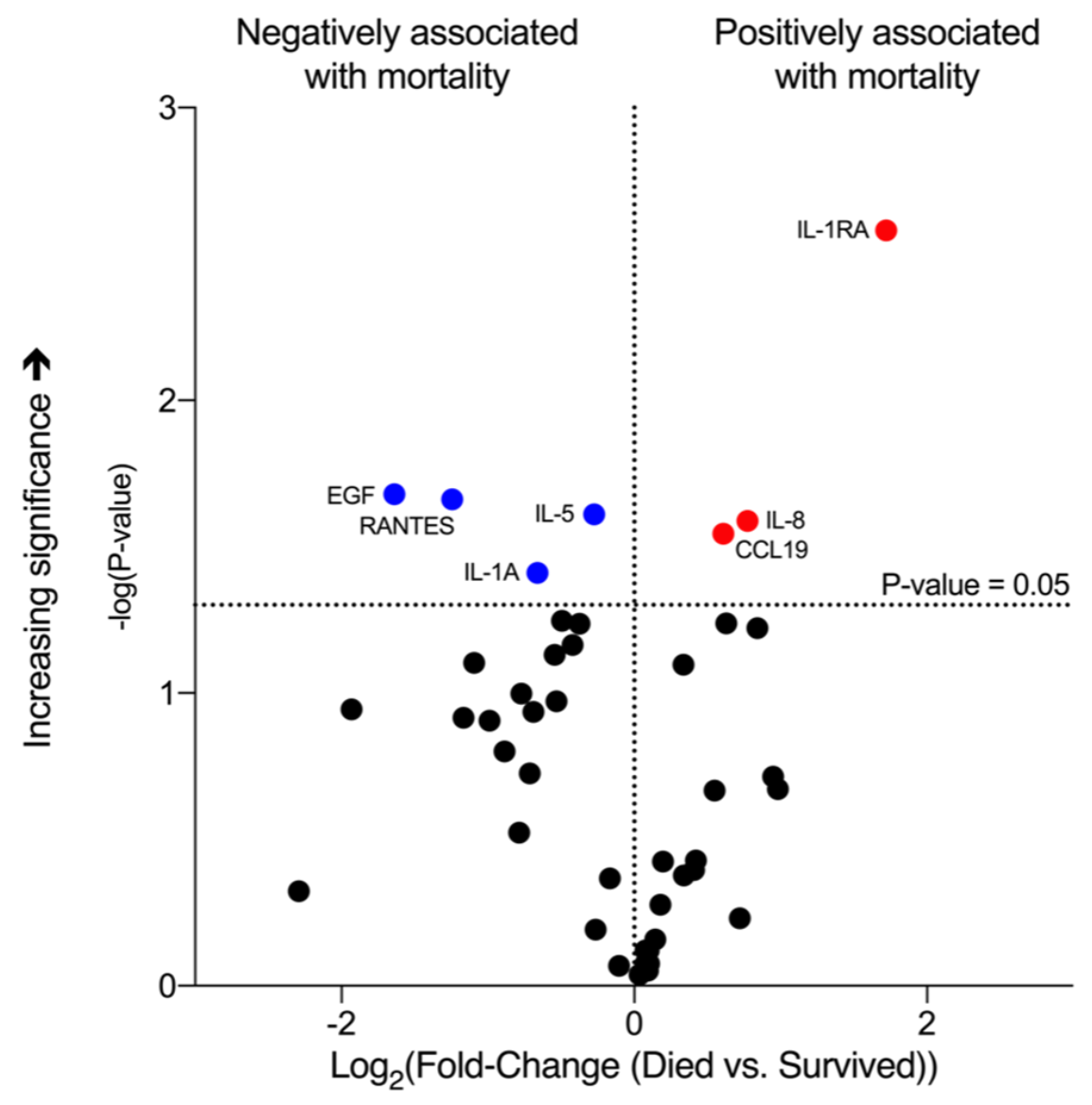

Figure 1: Cytokine determinations at the time of enrollment and association with mortality based on multiplex system determination. Volcano plot showing cytokines/chemokines significantly associated with mortality: blue dots, negatively associated; red dots, positively associated. Black dots identify entities not statistically significantly associated with mortality. Threshold of significance was established at a $p$ value of 0.05 before adjustment for false discovery rate. 
medRxiv preprint doi: https://doi.org/10.1101/2020.05.21.20051300; this version posted August 18, 2020. The copyright holder for this preprint (which was not certified by peer review) is the author/funder, who has granted medRxiv a license to display the preprint in perpetuity.

It is made available under a CC-BY-NC 4.0 International license .

Balnis et.al.

Figure 2
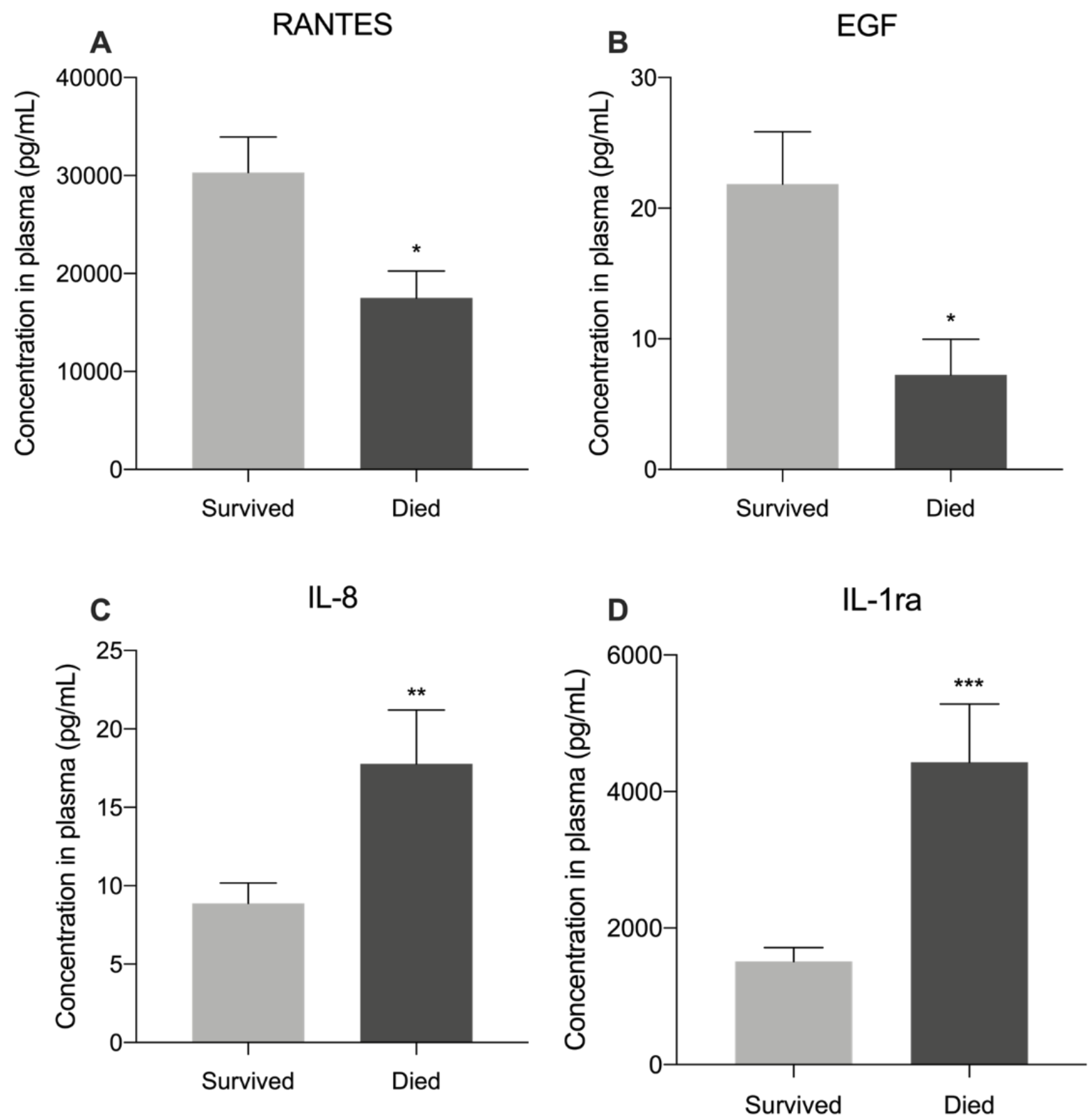

Figure 2: Cytokines associated with mortality based on ELISA tests performed individually. Bar graphs showing the cytokines/chemokines that were found associated with mortality by ELISA testing. ${ }^{*} p<0.05 ;{ }^{* *} p<0.01 ;{ }^{* * *} p<0.001$. 
medRxiv preprint doi: https://doi.org/10.1101/2020.05.21.20051300; this version posted August 18, 2020. The copyright holder for this preprint (which was not certified by peer review) is the author/funder, who has granted medRxiv a license to display the preprint in perpetuity.

It is made available under a CC-BY-NC 4.0 International license .

Balnis et.al.

\section{Supplementary Tables}

\begin{tabular}{|lll|}
\hline Table S1: ELISA kits & & \\
Target protein & Manufacturer & Product number \\
RANTES & Abcam & ab174446 \\
EGF & Abcam & ab217772 \\
CCL19 & R\&D Systems & DY361 \\
L-1ra & Abcam & ab211650 \\
L-8 & R\&D Systems & D $8000 C$ \\
L-1a & Abcam & ab178008 \\
L-5 & Abcam & $a b 215536$ \\
\hline
\end{tabular}

\begin{tabular}{|lll|}
\hline Table S2: qPCR primers & & \\
Target gene & Forward & Reverse \\
RANTES & CCTGCTGCTTTGCCTACATTGC & ACACACTTGGCGGTTCTTTCGG \\
EGF & TGCGATGCCAAGCAGTCTGTGA & GCATAGCCCAATCTGAGAACCAC \\
L-1ra & ATGGAGGGAAGATGTGCCTGTC & GTCCTGCTTTCTGTTCTCGCTC \\
L-8 & GAGAGTGATTGAGAGTGGACCAC & CACAACCCTCTGCACCCAGTTT \\
\hline
\end{tabular}

\section{Supplementary Figure}

Figure S1

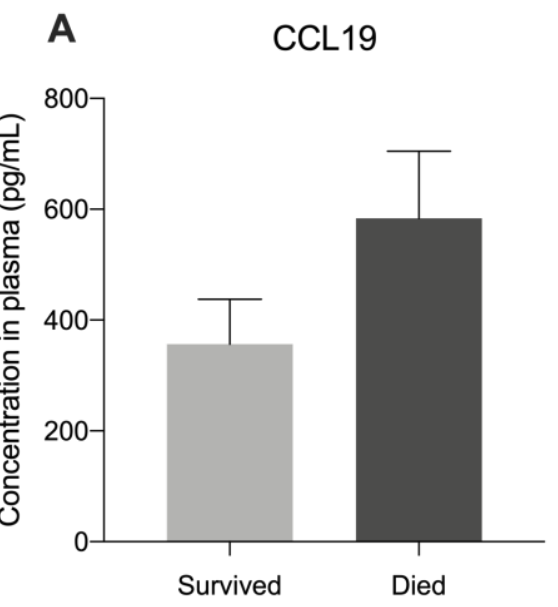

B

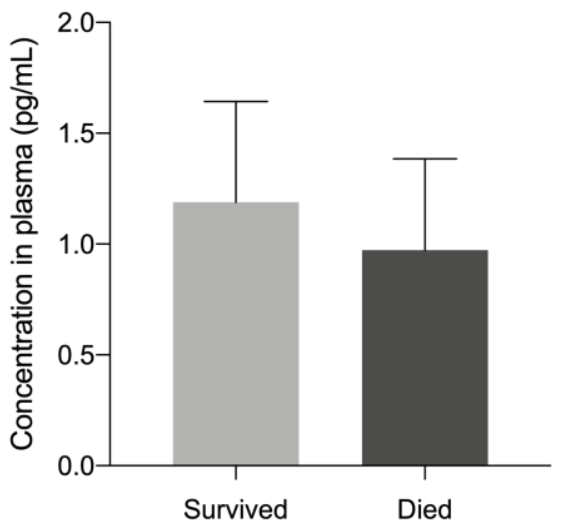

C

IL-1a

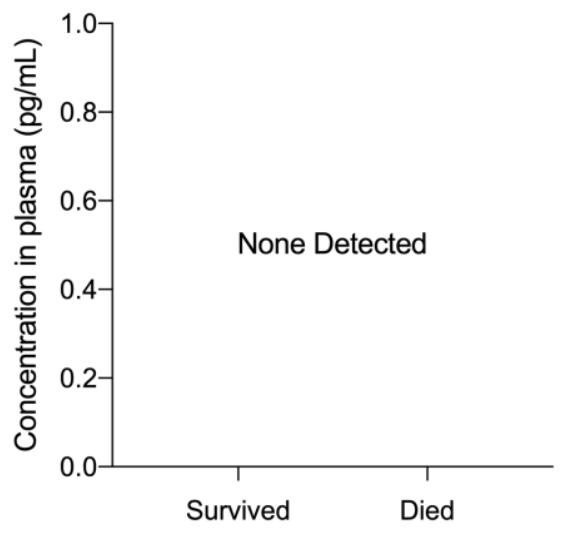


medRxiv preprint doi: https://doi.org/10.1101/2020.05.21.20051300; this version posted August 18, 2020. The copyright holder for this preprint (which was not certified by peer review) is the author/funder, who has granted medRxiv a license to display the preprint in perpetuity. It is made available under a CC-BY-NC 4.0 International license .

Balnis et.al.

\section{References}

1

3

4

Guan, W. J. et al. Clinical Characteristics of Coronavirus Disease 2019 in China. N Engl J Med, doi:10.1056/NEJMoa2002032 (2020).

Wilson, J. G. et al. Cytokine profile in plasma of severe COVID-19 does not differ from ARDS and sepsis. JCI Insight, doi:10.1172/jci.insight.140289 (2020).

Zhao, Y. et al. Longitudinal COVID-19 profiling associates IL-1RA and IL-10 with disease severity and RANTES with mild disease. JCl Insight 5, doi:10.1172/jci.insight.139834 (2020).

Calfee, C. S. et al. Acute respiratory distress syndrome subphenotypes and differential response to simvastatin: secondary analysis of a randomised controlled trial. Lancet Respir Med 6, 691-698, doi:10.1016/S2213-2600(18)30177-2 (2018).

Calfee, C. S. et al. Subphenotypes in acute respiratory distress syndrome: latent class analysis of data from two randomised controlled trials. Lancet Respir Med 2, 611-620, doi:10.1016/S22132600(14)70097-9 (2014).

Famous, K. R. et al. Acute Respiratory Distress Syndrome Subphenotypes Respond Differently to Randomized Fluid Management Strategy. Am J Respir Crit Care Med 195, 331-338, doi:10.1164/rccm.201603-06450C (2017).

Sinha, P. et al. Latent class analysis of ARDS subphenotypes: a secondary analysis of the statins for acutely injured lungs from sepsis (SAILS) study. Intensive Care Med 44, 1859-1869, doi:10.1007/s00134-018-5378-3 (2018).

Delucchi, K. et al. Stability of ARDS subphenotypes over time in two randomised controlled trials. Thorax 73, 439-445, doi:10.1136/thoraxjnl-2017-211090 (2018).

Sinha, P., Matthay, M. A. \& Calfee, C. S. Is a "Cytokine Storm" Relevant to COVID-19? JAMA Intern Med, doi:10.1001/jamainternmed.2020.3313 (2020).

Cummings, M. J. et al. Epidemiology, clinical course, and outcomes of critically ill adults with COVID-19 in New York City: a prospective cohort study. Lancet 395, 1763-1770, doi:10.1016/S01406736(20)31189-2 (2020).

1 Zhou, F. et al. Clinical course and risk factors for mortality of adult inpatients with COVID-19 in Wuhan, China: a retrospective cohort study. Lancet 395, 1054-1062, doi:10.1016/S0140-6736(20)30566-3 (2020).

12 Wu, C. et al. Risk Factors Associated With Acute Respiratory Distress Syndrome and Death in Patients With Coronavirus Disease 2019 Pneumonia in Wuhan, China. JAMA Intern Med, doi:10.1001/jamainternmed.2020.0994 (2020).

Mo, P. et al. Clinical characteristics of refractory COVID-19 pneumonia in Wuhan, China. Clin Infect Dis, doi:10.1093/cid/ciaa270 (2020).

4 Qin, C. et al. Dysregulation of Immune Response in Patients With Coronavirus 2019 (COVID-19) in Wuhan, China. Clin Infect Dis 71, 762-768, doi:10.1093/cid/ciaa248 (2020).

15 Fraser, D. D. et al. Inflammation Profiling of Critically III Coronavirus Disease 2019 Patients. Crit Care Explor 2, e0144, doi:10.1097/CCE.0000000000000144 (2020).

Wang, Y. et al. Clinical Course and Outcomes of 344 Intensive Care Patients with COVID-19. Am J Respir Crit Care Med 201, 1430-1434, doi:10.1164/rccm.202003-0736LE (2020).

Lucas, C. et al. Longitudinal analyses reveal immunological misfiring in severe COVID-19. Nature, doi:10.1038/s41586-020-2588-y (2020).

Benjamini, Y. Simultaneous and selective inference: Current successes and future challenges. Biom J 52, 708-721, doi:10.1002/bimj.200900299 (2010). 
medRxiv preprint doi: https://doi.org/10.1101/2020.05.21.20051300; this version posted August 18, 2020. The copyright holder for this preprint (which was not certified by peer review) is the author/funder, who has granted medRxiv a license to display the preprint in perpetuity. It is made available under a CC-BY-NC 4.0 International license .

Balnis et.al.

19 Antcliffe, D. B. et al. Transcriptomic Signatures in Sepsis and a Differential Response to Steroids. From the VANISH Randomized Trial. Am J Respir Crit Care Med 199, 980-986, doi:10.1164/rccm.20180714190C (2019).

20 Collins, F. S. \& Varmus, H. A new initiative on precision medicine. N Engl J Med 372, 793-795, doi:10.1056/NEJMp1500523 (2015).

21 Bos, L. D. et al. Identification and validation of distinct biological phenotypes in patients with acute respiratory distress syndrome by cluster analysis. Thorax 72, 876-883, doi:10.1136/thoraxjnl-2016209719 (2017).

22 Davenport, E. E. et al. Genomic landscape of the individual host response and outcomes in sepsis: a prospective cohort study. Lancet Respir Med 4, 259-271, doi:10.1016/S2213-2600(16)00046-1 (2016).

23 Balnis, J. et al. Higher plasma levels of Chemokine CCL19 are associated with poor SARS-CoV-2 acute respiratory distress syndrome (ARDS) outcomes. medRxiv, doi:10.1101/2020.05.21.20051300 (2020).

24 Zou, X. et al. Acute Physiology and Chronic Health Evaluation II Score as a Predictor of Hospital Mortality in Patients of Coronavirus Disease 2019. Crit Care Med 48, e657-e665, doi:10.1097/CCM.0000000000004411 (2020).

25 Charlson, M. E., Pompei, P., Ales, K. L. \& MacKenzie, C. R. A new method of classifying prognostic comorbidity in longitudinal studies: development and validation. J Chronic Dis 40, 373-383, doi:10.1016/0021-9681(87)90171-8 (1987).

$26 \mathrm{Li}, \mathrm{X}$. \& Ma, X. Acute respiratory failure in COVID-19: is it "typical" ARDS? Crit Care 24, 198, doi:10.1186/s13054-020-02911-9 (2020).

27 Yancy, C. W. COVID-19 and African Americans. JAMA, doi:10.1001/jama.2020.6548 (2020).

28 Shankar-Hari, M., Fan, E. \& Ferguson, N. D. Acute respiratory distress syndrome (ARDS) phenotyping. Intensive Care Med 45, 516-519, doi:10.1007/s00134-018-5480-6 (2019).

29 Pugin, J., Ricou, B., Steinberg, K. P., Suter, P. M. \& Martin, T. R. Proinflammatory activity in bronchoalveolar lavage fluids from patients with ARDS, a prominent role for interleukin-1. Am J Respir Crit Care Med 153, 1850-1856, doi:10.1164/ajrccm.153.6.8665045 (1996).

30 Pugin, J., Verghese, G., Widmer, M. C. \& Matthay, M. A. The alveolar space is the site of intense inflammatory and profibrotic reactions in the early phase of acute respiratory distress syndrome. Crit Care Med 27, 304-312, doi:10.1097/00003246-199902000-00036 (1999).

31 Lee, Y. M. et al. Platelet-activating factor contributes to acute lung leak in rats given interleukin-1 intratracheally. Am J Physiol Lung Cell Mol Physiol 279, L75-80, doi:10.1152/ajplung.2000.279.1.L75 (2000).

32 Roux, J. et al. Interleukin-1beta decreases expression of the epithelial sodium channel alpha-subunit in alveolar epithelial cells via a p38 MAPK-dependent signaling pathway. J Biol Chem 280, 18579-18589, doi:10.1074/jbc.M410561200 (2005).

33 Herold, S. et al. Exudate macrophages attenuate lung injury by the release of IL-1 receptor antagonist in gram-negative pneumonia. Am J Respir Crit Care Med 183, 1380-1390, doi:10.1164/rccm.20100914310C (2011).

34 Donnelly, S. C. et al. The association between mortality rates and decreased concentrations of interleukin-10 and interleukin-1 receptor antagonist in the lung fluids of patients with the adult respiratory distress syndrome. Ann Intern Med 125, 191-196, doi:10.7326/0003-4819-125-3199608010-00005 (1996).

35 Chada, M. et al. Anakinra (IL-1R antagonist) lowers pulmonary artery pressure in a neonatal surfactant depleted piglet model. Pediatr Pulmonol 43, 851-857, doi:10.1002/ppul.20851 (2008). 
medRxiv preprint doi: https://doi.org/10.1101/2020.05.21.20051300; this version posted August 18, 2020. The copyright holder for this preprint (which was not certified by peer review) is the author/funder, who has granted medRxiv a license to display the preprint in perpetuity. It is made available under a CC-BY-NC 4.0 International license .

Balnis et.al.

36 Ortiz, L. A. et al. Interleukin 1 receptor antagonist mediates the antiinflammatory and antifibrotic effect of mesenchymal stem cells during lung injury. Proc Natl Acad Sci U S A 104, 11002-11007, doi:10.1073/pnas.0704421104 (2007).

37 Meyer, N. J. et al. IL1RN coding variant is associated with lower risk of acute respiratory distress syndrome and increased plasma IL-1 receptor antagonist. Am J Respir Crit Care Med 187, 950-959, doi:10.1164/rccm.201208-15010C (2013).

38 Cavalli, G. et al. Interleukin-1 blockade with high-dose anakinra in patients with COVID-19, acute respiratory distress syndrome, and hyperinflammation: a retrospective cohort study. Lancet Rheumatol 2, e325-e331, doi:10.1016/S2665-9913(20)30127-2 (2020).

39 Cauchois, R. et al. Early IL-1 receptor blockade in severe inflammatory respiratory failure complicating COVID-19. Proc Natl Acad Sci U S A, doi:10.1073/pnas.2009017117 (2020).

40 Cocchi, F. et al. Identification of RANTES, MIP-1 alpha, and MIP-1 beta as the major HIV-suppressive factors produced by CD8+ T cells. Science 270, 1811-1815, doi:10.1126/science.270.5243.1811 (1995).

41 Liao, M. et al. Single-cell landscape of bronchoalveolar immune cells in patients with COVID-19. Nat Med 26, 842-844, doi:10.1038/s41591-020-0901-9 (2020).

42 Bos, L. D. J. et al. Understanding Heterogeneity in Biologic Phenotypes of Acute Respiratory Distress Syndrome by Leukocyte Expression Profiles. Am J Respir Crit Care Med 200, 42-50, doi:10.1164/rccm.201809-18080c (2019).

43 Wong, H. R. et al. Developing a clinically feasible personalized medicine approach to pediatric septic shock. Am J Respir Crit Care Med 191, 309-315, doi:10.1164/rccm.201410-18640C (2015).

44 Rangel-Moreno, J., Moyron-Quiroz, J. E., Hartson, L., Kusser, K. \& Randall, T. D. Pulmonary expression of CXC chemokine ligand 13, CC chemokine ligand 19, and CC chemokine ligand 21 is essential for local immunity to influenza. Proc Natl Acad Sci U S A 104, 10577-10582, doi:10.1073/pnas.0700591104 (2007).

45 Spits, H. et al. Innate lymphoid cells--a proposal for uniform nomenclature. Nat Rev Immunol 13, 145149, doi:10.1038/nri3365 (2013). 